\title{
Vertical distribution of sulfate-reducing bacteria in the chemocline of Lake Cadagno, Switzerland, over an annual cycle
}

\author{
Sandro Peduzzi ${ }^{1,2, * *}$, Mauro Tonolla ${ }^{1, * *}$, Dittmar Hahn ${ }^{2, *}$ \\ ${ }^{1}$ Cantonal Institute of Microbiology, Microbial Ecology (University of Geneva), Via Giuseppe Buffi 6, 6904 Lugano, Switzerland \\ ${ }^{2}$ Department of Chemical Engineering, New Jersey Institute of Technology (NJIT) and Department of Biological Sciences, Rutgers University, \\ 101 Warren Street, Smith Hall 135, Newark, New Jersey 07102-1811, USA
}

\begin{abstract}
Sulfate-reducing bacteria were analyzed in the chemocline of meromictic Lake Cadagno, Switzerland, in March, June, August and October using in situ hybridization. Numbers of sulfate-reducing bacteria determined as the sum of cells hybridizing to Probes SRB385Db targeting Desulfobacteriaceae and SRB385 targeting Desulfovibrionaceae were similar at all samplings and accounted for 13 to $18 \%$ of the total microbial community, respectively. Abundance of cells detected with either probe, however, changed during the year, with cell numbers detected with SRB385Db being larger in early summer (June) and those detected with SRB385 being larger in late summer (October). Increasing cell numbers detected with SRB385Db were mainly caused by a yet uncultured and phylogenetically unidentified bacterium with a peculiar morphology ('Morphotype R') that followed the sulfide profile in June as well as in August with increasing numbers at increasing concentrations with depth. From the fraction of cells detected with SRB385, only a minor part represented a yet uncultured population without close cultured relatives. At all samplings, the majority of cells detected with SRB385 (93 to 99\%) represented populations phylogenetically related to Desulfocapsa thiozymogenes DSM7269. Their cells were generally found in association with aggregates of small-celled phototrophic sulfur bacteria. This association was not specific for 1 of the 4 populations representing all small-celled phototrophic sulfur bacteria in Lake Cadagno. The association was also not obligate since non-associated cells were frequently found, especially in winter and early summer when limited light conditions caused by snow and ice cover reduced the abundance of small-celled phototrophic sulfur bacteria to about $50 \%$ of the values found in late summer. Nonetheless, the association between populations related to $D$. thiozymogenes and small-celled phototrophic sulfur bacteria suggests an ecological advantage to both organisms under appropriate environmental conditions.
\end{abstract}

KEY WORDS: Aggregates - Chemocline - In situ hybridization - Meromictic lake - Purple sulfur bacteria - Sulfatereducing bacteria

Resale or republication not permitted without written consent of the publisher

\footnotetext{
*Corresponding author. Email: hahn@andromeda.rutgers.edu

** Sandro Peduzzi and Mauro Tonolla contributed equally to the study
}

Lake Cadagno is a meromictic lake located $1923 \mathrm{~m}$ above sea level in the southern Alps of Switzerland $\left(46^{\circ} 33^{\prime} \mathrm{N}, 8^{\circ} 43^{\prime} \mathrm{E}\right)$, in the catchment area of a dolomite vein rich in gypsum (Piora-Mulde). A permanent chemocline at a depth between 9 and $14 \mathrm{~m}$ ( Wagener et al. 1990, Peduzzi et al. 1993) is stabilized by density differences of salt-rich water constantly supplied by subaquatic springs to the monimolimnion and of electrolyte-poor surface water feeding the mixolimnion (Del Don et al. 2001). High concentrations of sulfate and steep sulfide gradients in the chemocline (Hanselmann \& Hutter 1998, Lehmann et al. 1998) support the growth of large numbers of bacteria (up to $10^{7}$ cells ml ${ }^{-1}$ ), indicating that a bacterial community making use of these gradients is present (Tonolla et al. 1998a, 1999). Molecular techniques that were used to analyze microbial community structure unaffected by the limitations of culturability showed that almost all bacteria in this chemocline belonged to the Proteobacteria (Tonolla et al. 1998a, 1999), with numbers for the $\alpha-, \beta-, \gamma$ - and $\delta$ subdivisions of Proteobacteria accounting for 23, 17, 45 and $15 \%$ of the total number of bacteria, respectively (Tonolla et al. 1998a, 1999). Most prominent numerically (ca. $33 \%$ of all bacteria) were large- and smallcelled phototrophic purple sulfur bacteria (Peduzzi et al. 1993, Fischer et al. 1996, Tonolla et al. 1998a, 1999). These large-celled phototrophic sulfur bacteria were identified as Chromatium okenii, while small-celled phototrophic sulfur bacteria consisted of 4 major populations forming a tight cluster with Lamprocystis purpurea (former Amoebobacter purpureus and Pfennigia purpurea) and L. roseopersicina (Tonolla et al. 1999). These small-celled phototrophic sulfur bacteria were usually found in aggregates, together with sulfatereducing bacteria of the family Desulfovibrionaceae (Tonolla et al. 1998a, 1999). Based on comparative sequence analysis of a 16S rRNA gene clone library, the latter were separated into 2 groups. One group, repre- 
sented by a cluster of sequences closely related to Desulfocapsa thiozymogenes DSM7269, resembled cells that were generally associated with aggregates of small-celled phototrophic sulfur bacteria, while the other group consisted of cells represented by a second cluster that were free-living or loosely attached to other cells or debris, similar to sulfate-reducing bacteria of the family Desulfobacteriaceae (Tonolla et al. 2000). Since the populations of small-celled phototrophic sulfur bacteria differentially distributed along the chemocline, which indicates different ecophysiological adaptations (Tonolla et al. 1999), we were interested in further analyzing the vertical distribution of sulfate-reducing bacteria in the chemocline of Lake Cadagno over an annual cycle and to elucidate their interaction with the small-celled phototrophic sulfur bacteria.

For this purpose, water samples were collected from the chemocline over the center of the lake, at its deepest point $(21 \mathrm{~m}), 4$ times over a period of $1 \mathrm{yr}$ for chemical and bacterioplankton analyses. Four representative periods of the year were chosen as sampling dates: (1) the end of the summer season (October 14, 1998) before partial water mixing (only oxic mixolimnion) and surface freezing; (2) the middle of the winter season (March 24, 1999) when the lake was covered by a thick layer of ice and snow (about $2 \mathrm{~m}$ ); (3) the beginning of the summer season (June 16, 1999), just after the ice had melted; and (4) in the middle of the summer season (August 23, 1999). A thin layer pneumatic multi-syringe sampler was employed, which allowed the simultaneous collection of $100 \mathrm{ml}$ water samples in the chemocline with a resolution of $10 \mathrm{~cm}$ over a depth of $2 \mathrm{~m}$ (Tonolla et al. 1999). Basic physico-chemical parameters (temperature, conductivity, $\mathrm{pH}$, dissolved oxygen, turbidity and redox potential) were simultaneously measured with a YSI 6000 profiler (Yellow Springs) attached to the lowest part of the multisyringe sampler (Tonolla et al. 1999). In addition, photosynthetically active radiation (PAR) light transmission conditions were determined in $10 \mathrm{~cm}$ steps using 2 LI193SA spherical quantum sensors and a LI-COR 1000 datalogger. From the water samples, $11 \mathrm{ml}$ subsamples were immediately transferred to screw-capped tubes containing $0.8 \mathrm{ml}$ of a $4 \%$ zinc acetate solution that were stored on ice and used to determine sulfide concentrations colorimetrically (Gilboa-Garber 1971) with a Merck Spectroquant ${ }^{\circledR}$ kit (Tonolla et al. 1999, 2000). Additional water samples were further analyzed for soluble iron, ammonia and sulfate using standard protocols (DEV 2000).

Generated profiles generally agreed with those commonly obtained for chemocline samples of Lake Cadagno during the year (Tonolla et al. 1998b). The chemocline was located at a depth between 11 and $13 \mathrm{~m}$, except for March where it was found at a slightly lower depth (12 to $14 \mathrm{~m}$ ) (Fig. 1). Throughout the whole year, it was characterized by high conductivity (between 230 and $270 \mu \mathrm{S} \mathrm{cm}{ }^{-1}$ ) and sulfate (100 to $150 \mathrm{mg} \mathrm{l}^{-1}$ ) values. Low oxygen concentrations (below $1 \mathrm{mg} \mathrm{l}^{-1}$ ) were found in the upper part of the chemocline, but concentrations rapidly decreased with depth to undetectable values when sulfide concentrations increased (up to $7 \mathrm{mg} \mathrm{l}^{-1}$; Fig. 1). Sulfide profiles showed the typical steep gradients in the chemocline (Tonolla et al. 1999, Lüthy et al. 2000) (Fig. 1). Ammonia and soluble iron concentrations increased with depth from 0 up to $0.6 \mathrm{mg} \mathrm{l}^{-1}$ and from 0.02 to $0.09 \mathrm{mg}$ $\mathrm{l}^{-1}$, respectively (Tonolla et al. 1998b).

During the year, major differences in profiles were only displayed for light intensities and turbidities. In October, high light intensities $\left(4.2 \mu \mathrm{E} \mathrm{m} \mathrm{m}^{-2} \mathrm{~s}^{-1}\right)$ were detected in the upper part of the chemocline that significantly decreased with depth (Fig. 1). High turbidity values with up to 57 formazine turbidity units (FTU) at this time indicated the presence of a well-developed plume of microorganisms. Since the lake was covered by ice and snow $(2 \mathrm{~m})$ at the sampling in March, the light intensity in the chemocline was much lower, decreasing from 0.5 to $0.2 \mu \mathrm{E} \mathrm{m}^{-2} \mathrm{~s}^{-1}$ with an average of

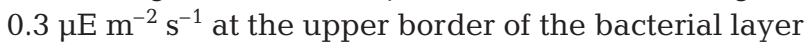
at a depth of $13.1 \mathrm{~m}$ (Fig. 1). The bacterial layer was less developed than in October as indicated by much lower values for turbidity (<8 FTU) (Fig. 1). After the ice cover had melted in June, about 10-fold higher light intensities reached the chemocline $\left(2.2 \mu \mathrm{E} \mathrm{m}{ }^{-2}\right.$ $\mathrm{s}^{-1}$ ), which also showed increasing turbidity values to about 16 FTU at a depth of $11.6 \mathrm{~m}$ (Fig. 1). At the 4th sampling in August 1999, light intensity was similar to that in October $\left(5.8 \mu \mathrm{E} \mathrm{m}^{-2} \mathrm{~s}^{-1}\right)$ and turbidity values up to 45 FTU indicated the establishment of a dense microbial community around a depth of $11.8 \mathrm{~m}$ (Fig. 1).

High turbidity values were generally found in a depth range where sulfide concentrations were increasing with depth from undetectable to up to 7-8 $\mathrm{mg}$ $\mathrm{l}^{-1}$ of sulfide (Fig. 1), suggesting the presence of both sulfide-producing as well as sulfide-consuming microbial populations in these plumes. This suggestion is supported by previous in situ analyses of sulfide turnover rates in the chemocline of Lake Cadagno that showed net sulfide consumption during the day and net sulfide production during the night at maximum turbidity (Lehmann et al. 1998, Lüthy et al. 2000). Net sulfide consumption at high light intensities during the day could be attributed to the large activity of phototrophic sulfur bacteria, and net sulfide production during the night to the activity of sulfate-reducing bacteria and the anaerobic respiration of internal storage compounds (biopolymers) of the phototrophic bacteria (Del Don et al. 1994, Mas \& Van Gemerden 1995). The steep gradient of sulfide in the chemocline of Lake 
Cadagno during periods of intensive photo-oxidation suggests that sulfide might even become limiting for phototrophic sulfur bacteria in the upper part of the bacterial plume (Lüthy et al. 2000), with different populations competing with each other. Interactions between these populations and sulfate-reducing bacteria might overcome sulfide limitations and support specific populations.

Bacterial populations were analyzed by in situ hybridization in $3 \mu \mathrm{l}$ aliquots of paraformaldehydefixed water samples $(n=3)$ spotted onto gelatin-coated slides (Glöckner et al. 1996). The analysis was performed with Cy3-labeled probes in a top-to-bottom approach initially focussing on sulfate-reducing bacteria of the families Desulfovibrionaceae (Probe SRB385) (Amann et al. 1990) and Desulfobacteriaceae (Probe SRB385Db) (Rabus et al. 1996) (Table 1). SRB385 and SRB385Db are generally used to analyze Gram-negative mesophilic sulfate-reducing bacteria (Manz et al. 1992, 1998, Tonolla et al. 2000) even though hybridiza- tion of both to other non-target organisms has been demonstrated. Within the Desulfovibrionaceae, 2 populations were subsequently analyzed: Desulfocapsa thiozymogenes and a cluster of 6 clones retrieved from the chemocline of Lake Cadagno were targeted by combined Probes DSC213 and DSC441, and a second cluster with no identified cultured relative was targeted by Probe SRB441 (Tonolla et al. 2000). The interaction of these populations with specific small-celled phototrophic sulfur bacteria was analyzed with Cy5labeled probes Apur453 targeting Lamprocystis purpurea DSM4197, Laro453 targeting Lamprocystis roseopersicina DSM229, and S453D and S453F, both targeting yet uncultured populations of phototrophic sulfur bacteria (Tonolla et al. 1999) (Table 1).

Hybridizations were performed in $9 \mu \mathrm{l}$ of hybridization buffer $(0.9 \mathrm{M} \mathrm{NaCl}, 20 \mathrm{mM}$ Tris/ $\mathrm{HCl}, \mathrm{pH} 7.2,5 \mathrm{mM}$ EDTA, $0.01 \%$ SDS) in the presence of 5 to $40 \%$ formamide depending on the probe (Table 1), $1 \mu$ l of the probe (25 $\mathrm{ng} \mathrm{\mu l}^{-1}$ ) and $1 \mu \mathrm{l}$ of a DAPI solution (200 ng

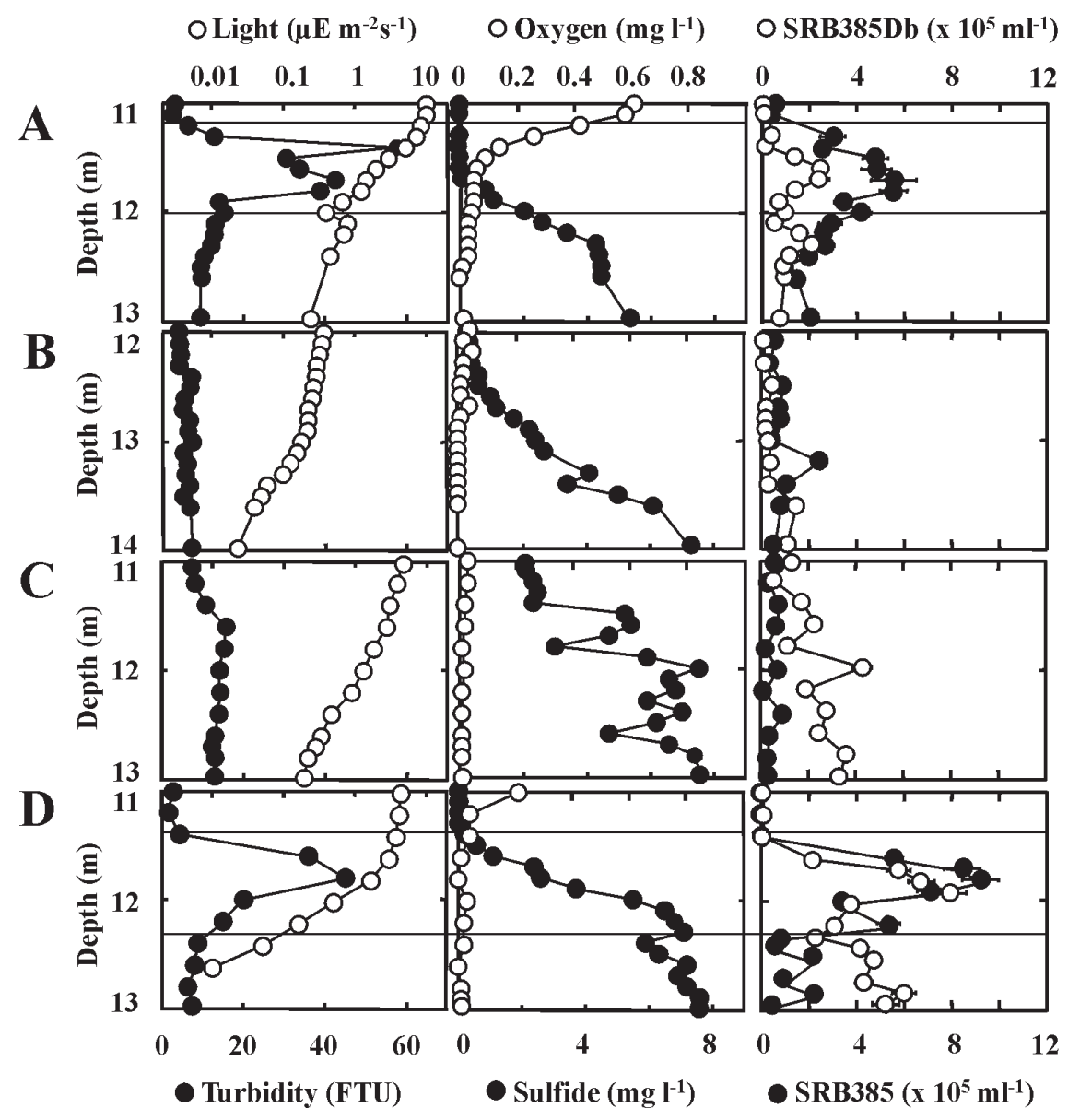

Fig. 1. Profiles of some physico-chemical characteristics (light, turbidity, oxygen and sulfide) and bacteria detected after in situ hybridization with Probes SRB385 and SRB385Db in the chemocline of Lake Cadagno in (A) October 1998, (B) March 1999,

(C) June 1999 and (D) August 1999. Data are presented as means \pm SE 
Table 1. Oligonucleotide probes

\begin{tabular}{|c|c|c|c|}
\hline Probe & Target & $\begin{array}{l}\text { Sequence }\left(5^{\prime}=>3^{\prime}\right) \\
(\% \text { formamide in hybridization buffer) }\end{array}$ & Source \\
\hline \multicolumn{4}{|c|}{ Sulfate-reducing bacteria } \\
\hline SRB385 & $\begin{array}{l}\text { Desulfovibrionaceae, and others } \\
\text { 16S rRNA, position 385-402 }\end{array}$ & $\begin{array}{l}\text { CGGCGTCGCTGCGTCAGG } \\
(20 \%)\end{array}$ & Amann et al. (1990) \\
\hline SRB385Db & $\begin{array}{l}\text { Desulfobacteriaceae, and others } \\
\text { 16S rRNA, position } 385-402\end{array}$ & $\begin{array}{l}\text { CGGCGTTGCTGCGTCAGG } \\
(30 \%)\end{array}$ & Rabus et al. (1996) \\
\hline SRB441 & $\begin{array}{l}\text { Clones } 141 \text { and } 22 \text { from Lake Cadagno } \\
\text { 16S rRNA, position } 441-459\end{array}$ & $\begin{array}{l}\text { CATGCACTTCTTTCCACTT } \\
(5 \%)\end{array}$ & Tonolla et al. (2000) \\
\hline DSC441 & $\begin{array}{l}\text { Clones } 113 \text { and } 330 \text { from Lake Cadagno } \\
\text { 16S rRNA, position } 441-459\end{array}$ & $\begin{array}{l}\text { ATTACACTTCTTCCCATCC } \\
(30 \%)\end{array}$ & Tonolla et al. (2000) \\
\hline DSC213 & $\begin{array}{l}\text { Desulfocapsa thiozymogenes (DSM7269) } \\
\text { Clones } 113 \text { and } 330 \text { from Lake Cadagno } \\
\text { 16S rRNA, position 213-230 }\end{array}$ & $\begin{array}{l}\text { CCTCCCTGTACGATAGCT } \\
(30 \%)\end{array}$ & Tonolla et al. (2000) \\
\hline \multicolumn{4}{|c|}{ Small-celled phototrophic sulfur bacteria } \\
\hline Apur453 & $\begin{array}{l}\text { Lamprocystis purpurea (DSM4197) } \\
\text { 16S rRNA, position } 453-479\end{array}$ & $\begin{array}{l}\text { TCGCCCAGGGTATTATCCCAAACGAC } \\
(40 \%)\end{array}$ & Tonolla et al. (1999) \\
\hline Laro453 & $\begin{array}{l}\text { Lamprocystis roseopersicina (DSM229) } \\
16 \text { S rRNA, position } 453-479\end{array}$ & $\begin{array}{l}\text { CATTCCAGGGTATTAACCCAAAATGC } \\
(40 \%)\end{array}$ & Tonolla et al. (1999) \\
\hline S453D & $\begin{array}{l}\text { Clone } 261 \text { from Lake Cadagno } \\
\text { 16S rRNA, position } 453-479\end{array}$ & $\begin{array}{l}\text { CAGCCCAGGGTATTAACCCAAGCCGC } \\
(30 \%)\end{array}$ & Tonolla et al. (1999) \\
\hline S453F & $\begin{array}{l}\text { Clone } 371 \text { from Lake Cadagno } \\
\text { 16S rRNA, position } 453-479\end{array}$ & $\begin{array}{l}\text { CCCTCATGGGTATTARCCACAAGGCG } \\
(35 \%)\end{array}$ & Tonolla et al. (1999) \\
\hline
\end{tabular}

$\mu \mathrm{l}^{-1}$ ) at $46^{\circ} \mathrm{C}$ for $2 \mathrm{~h}$ (Zarda et al. 1997). After hybridization, the slides were washed in buffer containing $20 \mathrm{mM}$ Tris/HCl, pH 7.2, 10 mM EDTA, 0.01\% SDS and either $636,318,112,80$ or $56 \mathrm{mM} \mathrm{NaCl}$ depending on the formamide concentration during hybridization $(5,20,30,35$, and $40 \%$, respectively) for $15 \mathrm{~min}$ at $48^{\circ} \mathrm{C}$, subsequently rinsed with distilled water, and airdried (Zarda et al. 1997). The slides were mounted with Citifluor AF1 immersion oil solution and examined with a Zeiss Axiolab microscope fitted for epifluorescence microscopy with a high-pressure mercury bulb and filter sets F31-000 (AHF Analysentechnik; D360/50, 400DCLP, D460/50, for DAPI detection), F41007 (HQ545/30, Q565LP, HQ610/75, for Cy3 detection), and F41-008 (HQ620/60, Q660LP, HQ700/75, for Cy5 detection), respectively. Microorganisms were counted at $1000 \times$ magnification in 40 fields covering an area of $0.01 \mathrm{~mm}^{2}$ each (Tonolla et al. 2000). Numbers were expressed as mean $\pm \mathrm{SE}$ and compared using Student's $t$-test with a significance level of 0.05 .

Microbial population density, as indicated by the numbers of cells determined after DAPI staining averaged across the whole chemocline, largely correlated to turbidity profiles (Fig. 1). Numbers declined between October and March from $22 \pm 3 \times 10^{5}$ to $8 \pm 1 \times$ $10^{5}$ cells ml ${ }^{-1}$, and then increased to $15 \pm 2 \times 10^{5}$ cells $\mathrm{ml}^{-1}$ in June and further to $50 \pm 4 \times 10^{5}$ cells ml ${ }^{-1}$ in August. Of the DAPI-stained cells, about 18, 13, 18 and $13 \%$ were detected with both Probes SRB385 and
SRB385Db in October, March, June and August, respectively (Table 2). These numbers are similar to those of other samplings (e.g. $23 \%$ in October 1997; Table 2) (Tonolla et al. 2000) and demonstrate the presence of a large and numerically relatively stable community of sulfate-reducing bacteria in the chemocline of Lake Cadagno as expected under the given environmental conditions (Fig. 1).

Over the annual cycle, however, differences were obtained in abundance of bacteria detected with either SRB385 or SRB385Db, although profiles of cell numbers detected with either probe corresponded roughly to each other and to the turbidity and DAPI profiles (Fig. 1). Cells detected with SRB385, however, were most prominent at the end of the summer $(12.9 \pm 1.7 \%$ of the DAPI-stained cells), while numbers detected with SRB385Db were much lower $(4.7 \pm 0.6 \%$ of the DAPI-stained cells) (Table 2). In contrast, numbers of cells detected with SRB385Db were much higher at the beginning of the summer. In June, for example, they accounted for $14.3 \pm 1.5 \%$ of the DAPI-stained cells, while SRB385 detected only $3.4 \pm 0.3 \%$ of the DAPIstained cells (Table 2). These results suggest different ecophysiological adaptations to environmental characteristics of fractions of sulfate-reducing bacteria detected with SRB385 and SRB385Db.

One potential candidate for each of the fractions of sulfate-reducing bacteria detected with SRB385 and SRB385Db was identified. Within the fraction of sul- 
fate-reducing bacteria detected with SRB385Db, the population of a bacterium with a peculiar morphology, previously described as 'Morphotype R' (Bensadoun et al. 1998), was shown to follow the sulfide profile in June as well as in August, with increasing numbers at increasing concentrations with depth (data not shown). This morphotype hybridized with SRB385Db and was observed in the bacterial plume, particularly in its lowest part and in the sampling of June. In a previous study, it was mainly detected in the monimolimnion of the lake and its presence was positively correlated with sulfide content and the redox potential (Bensadoun et al. 1998). Based on morphological features and habitat occurrence, a high similarity between the 'Morphotype R' and other yet uncultured bacteria (Morphotype T5) of anoxic waters was observed (Caldwell \& Tiedje 1975, Bensadoun et al. 1998). Representatives of the Morphotype T5, Desulfomonile tiedjei and $D$. liminaris, have been isolated and described (DeWeerd et al. 1990, Sun et al. 2001). The isolation techniques and media employed in those studies could eventually be used for isolation of 'Morphotype R' from Lake Cadagno, which would allow pure culture studies on potential metabolic capacities. Such studies would support ongoing attempts to obtain 16S rRNA sequence information from this morphotype which could be a basis for probe design and application to monitor population dynamics of 'Morphotype $\mathrm{R}$ ' in the water column and in the anoxic sediment of Lake Cadagno in order to obtain a more detailed picture about its abundance and ecophysiological adaptations.

Within the fraction of sulfate-reducing bacteria detected with probe SRB385, 2 groups were analyzed, but only one was important numerically. Only a small percentage of the DAPI-stained bacteria hybridized with probe SRB441, which represent yet uncultured free-living sulfate-reducing bacteria; these cells also hybridized with probe SRB385 (Tonolla et al. 2000). Averaged over the whole chemocline, they accounted for $1.2 \pm 0.2,0.2 \pm 0.0,0.2 \pm 0.0$ and $0.1 \pm 0.0 \%$ of the DAPI-stained bacteria in October, March, June and August, respectively (Table 2). They also only represented a very small fraction of the total sulfate-reducing populations (Desulfovibrionaceae and Desulfobacteriaceae), with percentages ranging between $1.1 \pm 0.1$ and $6.8 \pm 0.9 \%$. The major fraction of cells hybridizing with SRB385 was detected with a combination of probes DSC213 and DSC441, which targeted sulfatereducers closely related to Desulfocapsa thiozymogenes (Fig. 2). Between $93.1 \pm 10.9$ and $98.5 \pm 12.7 \%$ of the total number of cells detected with SRB385 also hybridized to DSC213 and DSC441. Most of the cells detected were found to be associated with small-celled phototrophic sulfur bacteria, as reported previously (Tonolla et al. 2000). The close association of these bacteria with aggregates of phototrophic sulfur bacteria, however, influenced the accurate determination of cell numbers. Since SRB385 alone exhibits lower signal intensities than DSC213 and DSC441 together, and the analysis is impacted by the 3-dimensional structure of the aggregates, the numbers of cells detected with SRB385 might be underestimated and, thus, percentages described above be overestimated. An indication for this assumption were detection rates in June and August, where hybridization with the combination of DSC213 and DSC441 resulted in higher cell numbers, although statistically not different, than with SRB385 (Table 2).

In addition to associated cells, hybridization with the combination of DSC213 and DSC441 also detected cells that were not associated with aggregates of phototrophic sulfur bacteria. These accounted for $0.3 \pm$ $0.0,1.5 \pm 0.2,1.6 \pm 0.2$ and $0.4 \pm 0.0 \%$ of the DAPIstained bacteria in October, March, June and August, respectively. In March and June, they represent a large proportion of the cells hybridizing with DSC213 and DSC441 $(18.5 \pm 2.0$ and $38.3 \pm 3.8 \%$, respectively). This was different in the October and August samples,

Table 2. Seasonal abundance of sulfate-reducing and phototrophic purple sulfur bacteria in the chemocline of Lake Cadagno (in $\%$ of DAPI-stained cells $)(\mathrm{X} \pm \mathrm{SE})$. nd: not determined

\begin{tabular}{|c|c|c|c|c|c|}
\hline Probe & Oct 97 & Oct 98 & Mar 99 & Jun 99 & Aug 99 \\
\hline DSC213 + DSC441 (associated) & $10.2 \pm 1.7$ & $12.3 \pm 1.6$ & $6.6 \pm 0.7$ & $2.7 \pm 0.3$ & $6.1 \pm 0.5$ \\
\hline DSC213 + DSC441 (free) & nd & $0.3 \pm 0.0$ & $1.5 \pm 0.3$ & $1.6 \pm 0.2$ & $0.4 \pm 0.1$ \\
\hline SRB441 (all) & $0.4 \pm 0.1$ & $1.2 \pm 0.2$ & $0.2 \pm 0.0$ & $0.2 \pm 0.0$ & $0.1 \pm 0.0$ \\
\hline SRB385 (all) & $13.9 \pm 2.3$ & $12.9 \pm 1.7$ & $8.7 \pm 0.9$ & $3.4 \pm 0.3$ & $6.1 \pm 0.5$ \\
\hline SRB385Db (all) & $9.0 \pm 1.5$ & $4.7 \pm 0.6$ & $3.9 \pm 0.4$ & $14.3 \pm 1.4$ & $7.2 \pm 0.6$ \\
\hline SRB385 + SRB385Db (all) & $22.8 \pm 3.7$ & $17.6 \pm 2.3$ & $12.6 \pm 1.3$ & $17.7 \pm 1.7$ & $13.3 \pm 1.1$ \\
\hline $\begin{array}{l}\text { Autofluorescence/morphology } \\
\text { (all small-celled phototrophic sulfur bacteria) }\end{array}$ & $27.5 \pm 4.8$ & $35.0 \pm 4.5$ & $19.5 \pm 2.2$ & $14.6 \pm 1.4$ & $28.0 \pm 2.3$ \\
\hline $\begin{array}{l}\text { Sum of all small-celled sulfur and sulfate- } \\
\text { reducing bacteria (SRB385 and SRB385Db) }\end{array}$ & $50.3 \pm 8.6$ & $52.6 \pm 6.8$ & $32.1 \pm 3.5$ & $32.3 \pm 3.1$ & $41.3 \pm 3.4$ \\
\hline
\end{tabular}




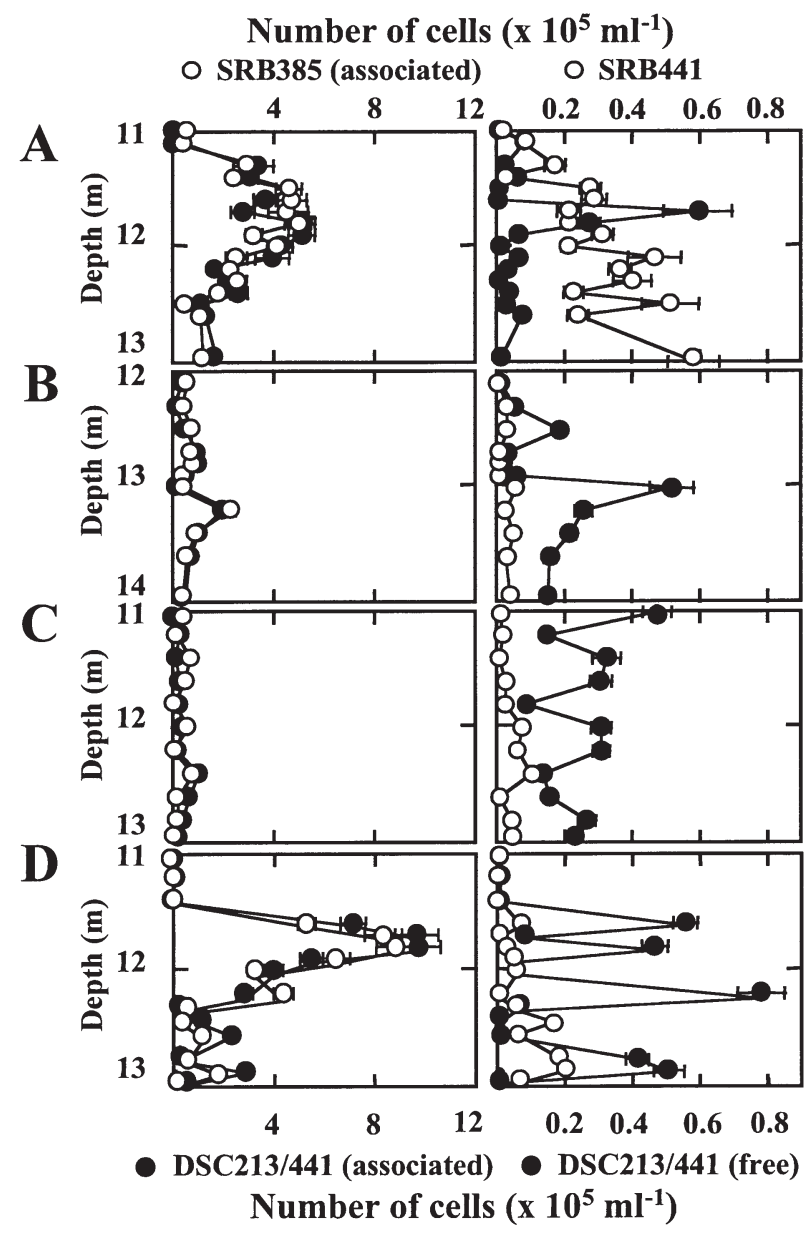

Fig. 2. Vertical distribution profiles of bacteria detected after in situ hybridization with Probe SRB385 or a combination of Probes DSC213 and DSC441 both representing cells associated to aggregates of phototrophic sulfur bacteria only, and with Probe SRB441 or Probes DSC213 and DSC441 both representing free cells (i.e. cells not associated to aggregates of phototrophic sulfur bacteria) in the chemocline of Lake Cadagno in (A) October 1998, (B) March 1999, (C) June 1999 and (D) August 1999. Data are presented as means $\pm \mathrm{SE}$

when only small percentages of $2.7 \pm 0.4$ and $5.9 \pm$ $0.5 \%$, respectively, of cells hybridizing with DSC213 and DSC441 were found in aggregates with smallcelled phototrophic sulfur bacteria (Table 2). These results suggested that the interaction between sulfatereducers closely related to Desulfocapsa thiozymogenes and small-celled phototrophic sulfur bacteria was not obligatory but promoted by environmental conditions.

The increase in non-associated cells and the concomitant decrease in associated cells was correlated to a decrease in abundance of small-celled phototrophic sulfur bacteria as experienced in March and June samples (Table 2). In these samples, small-celled phototrophic sulfur bacteria were present in small aggregates (ca. 5 to 40 cells) and accounted for about
20 and $15 \%$ of the DAPI-stained cells, respectively. These numbers were determined based on typical morphological characteristics (i.e. cell size) and the concomitant autofluorescence of the cells (Tonolla et al. 1998a, 1999). In August and October, much larger aggregates were encountered (ca. 200 to 900 cells) and numbers represented 28 and $35 \%$ of the DAPIstained cells (Table 2). Linear regression analysis (JMP Statistical Software, SAS Institute), in which small-celled phototrophic sulfur bacteria were taken as the independent variable, found a highly significant correlation between the total number of smallcelled phototrophic sulfur bacteria and the associated cells related to Desulfocapsa thiozymogenes (October: $\mathrm{R}^{2}=0.79, \mathrm{p}<0.0001 ;$ March: $\mathrm{R}^{2}=0.70, \mathrm{p}=0.0007$; June: $\mathrm{R}^{2}=0.81, \mathrm{p}=0.0001$; August, $\mathrm{R}^{2}=0.86, \mathrm{p}<$ 0.0001). Cells related to $D$. thiozymogenes, however, did not specifically associate with 1 of the 4 populations currently meant to represent all small-celled phototrophic sulfur bacteria, although these displayed different distribution profiles in the chemocline, suggesting different ecophysiological adaptations (Tonolla et al. 2000). DSC213 and DSC441 detected cells in aggregates formed by all 4 populations as shown by in situ hybridization concomitantly using Cy3labeled probes that targeted bacteria related to $D$. thiozymogenes and Cy5-labeled probes that targeted the specific populations of small-celled phototrophic sulfur bacteria (Fig. 3). Although these results did not provide evidence for a specific interrelationship between a single population of small celled phototrophic sulfur bacteria and cells related to D. thiozymogenes, they provide strong evidence of a tight association between small-celled phototrophic sulfur bacteria and bacteria related to $D$. thiozymogenes.

Since the interaction is specific for sulfate-reducing bacteria related to Desulfocapsa thiozymogenes, specific traits of this bacterium can be used as further indications on the potential interactions that may take place in the aggregate even though phylogenetic relationships do not necessarily reflect physiological relationships (Pace 1999, Achenbach \& Coates 2000, Zinder \& Salyers 2001). In addition to sulfate reduction, D. thiozymogenes DSM7269 can grow by disproportionation of thiosulfate and sulfite to sulfate and sulfide (Janssen et al. 1996). Similar to D. sulfoexigens DSM10523 and Desulfobulbus propionicus DSM2032 (Lovely \& Phillips 1994, Finster et al. 1998), D. thiozymogenes can also grow by disproportionation of elemental sulfur, although only in the presence of a sulfide scavenger such as amorphous ferric hydroxide; this generally results in the formation of sulfate along with iron sulfides (Thamdrup et al. 1993, Lovely \& Phillips 1994) and, thus, removes free sulfide from the culture (Janssen et al. 1996). Since the small-celled 

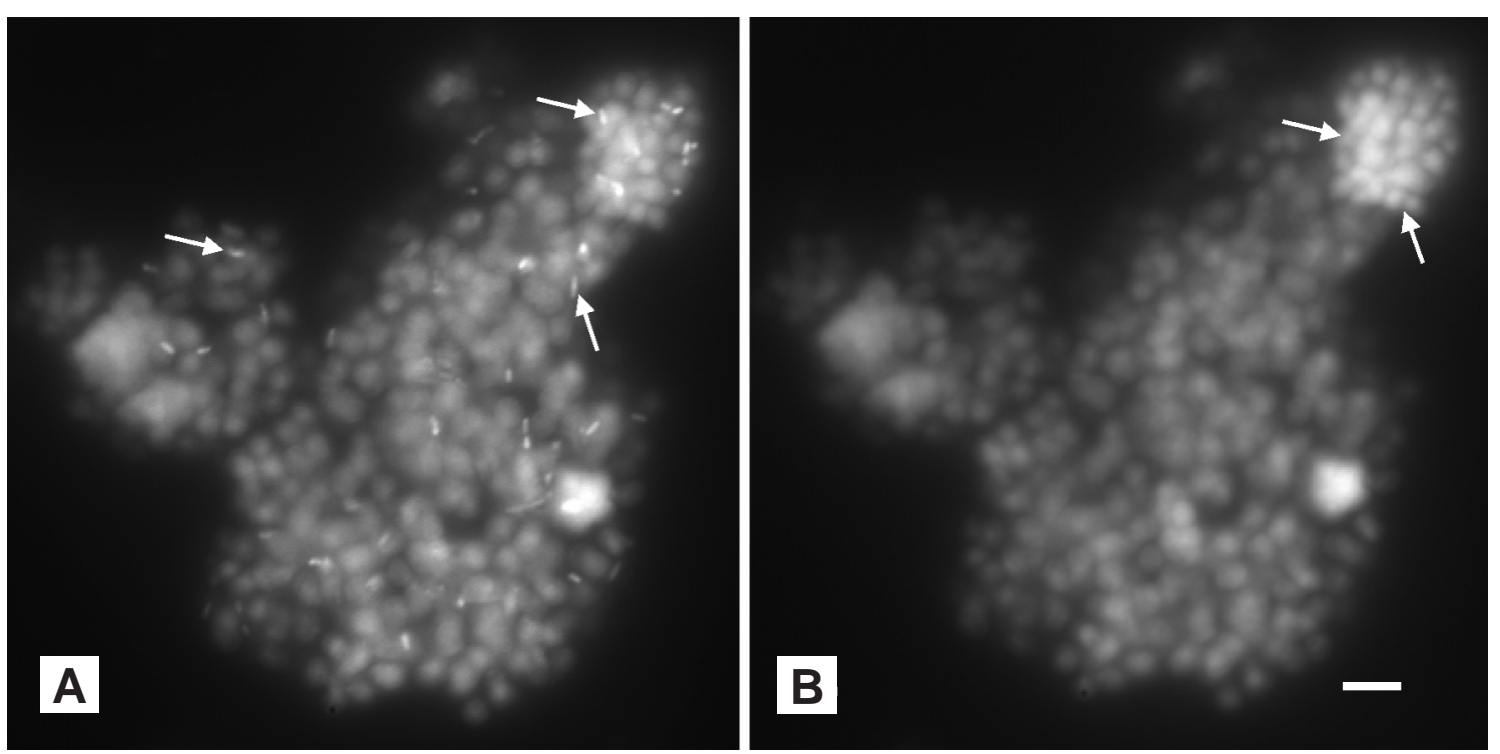

Fig. 3. (A) In situ detection of sulfate-reducing bacteria related to Desulfocapsa thiozymogenes with Cy3-labeled Probes DSC213 and DSC441. (B) Concomitantly, yet uncultured small-celled phototrophic sulfur bacteria (Population F) were detected with Cy5labeled Probe S453F as shown in the upper right portion of the aggregate. The remaining cells represent autofluorescent, nontarget small-celled phototrophic sulfur bacteria. Arrows indicate hybridizing cells. Scale bar $=10 \mu \mathrm{m}$

phototrophic sulfur bacteria Lamprocystis purpurea and L. roseopersicina both photo-oxidize sulfide to sulfur and further to sulfate (Eichler \& Pfennig 1988, Imhoff 2001), small-celled phototrophic sulfur bacteria in the chemocline of Lake Cadagno might act as sulfide scavengers, creating a sink for sulfide produced by sulfur disproportionation of the sulfate-reducing bacteria in the association. The interaction might be mutualistic since either sulfate-reduction or disproportionation in association with aggregates of small-celled phototrophic sulfur bacteria might overcome sulfide limitations of small-celled phototrophic sulfur bacteria during periods of intensive photo-oxidation.

In addition to sulfide, members of the genus Lamprocystis can also photo-oxidize elemental sulfur and thiosulfate (Imhoff 2001). During photo-oxidation, globules of elemental sulfur are stored intracellularly as intermediary oxidation products which can be further oxidized or, in the dark, be reduced by oxidation of internal storage products like glycogen (Mas \& Van Gemerden 1995). Under such conditions, an association with sulfate-reducing bacteria would be commensalistic since it would not provide an obvious advantage for the phototrophic sulfur bacteria. However, since both organisms are metabolically highly versatile, interactions may not be limited to sulfur compounds only. During sulfate reduction and concomitant oxidation of organic substrates, small organic molecules such as acetate might be excreted by the sulfatereducing bacteria which could further be used by small-celled phototrophic bacteria that grow under mixotrophic conditions (Eichler \& Pfennig 1988). Also, an association creates relatively stable microenvironmental conditions in a habitat where bioturbation phenomena or continuous movement of the plume due to chemo- or phototaxis result in rapid changes of environmental conditions (e.g. intensity of light, sulfide concentrations) (Egli et al. 1998, Hanselmann \& Hutter 1998, Lüthy et al. 2000).

Thus, the association between small-celled phototrophic sulfur bacteria and bacteria related to Desulfocapsa thiozymogenes could be commensalistic or mutualistic. However, the fundamental interactions between both organisms can only be elucidated with detailed pure culture studies on both partners of the association. Future perspectives will therefore focus on the isolation of both small-celled phototrophic sulfur bacteria and the bacteria related to $D$. thiozymogenes from the chemocline of Lake Cadagno, on the evaluation of their metabolic capacity and similarity with their closest cultured relatives, on the demonstration of aggregate formation and association of both organisms in vitro and the demonstration of beneficial effects of mixed cultures on the growth performance of both organisms.

Acknowledgements. This work was supported by grants from the Swiss National Science Foundation (SNSF) (NF3146855.96) and the canton of Ticino (Switzerland). During the work in the USA, S.P. was supported by a fellowship from the SNSF Commission of the University of the Italian-speaking Switzerland (81IT-59640). The authors are indebted to N. Ruggeri and A. Caminada for technical support. 


\section{LITERATURE CITED}

Achenbach LA, Coates JD (2000) Disparity between bacterial phylogeny and physiology. ASM News 66:714-715

Amann RI, Binder BJ, Olsen RJ, Chisholm SW, Devereux R, Stahl DA (1990) Combination of 16S rRNA-targeted oligonucleotide probes with flow cytometry for analyzing mixed microbial populations. Appl Environ Microbiol 56:1919-1925

Bensadoun JC, Tonolla M, Demarta A, Barja F, Peduzzi R (1998) Vertical distribution and microscopic characterization of a non-cultivable micro-organism (morphotype R) of Lake Cadagno. Doc Ist Ital Idrobiol 63:45-51

Caldwell DE, Tiedje JM (1975) A morphological study of anaerobic bacteria from the hypolimnia of 2 Michigan lakes. Can J Microbiol 21:362-376

Del Don C, Hanselmann KW, Peduzzi R, Bachofen R (1994) Biomass composition and methods for the determination of metabolic reserve polymers in phototrophic sulfur bacteria. Aquat Sci 56:1-15

Del Don C, Hanselmann KW, Peduzzi R, Bachofen R (2001) The meromictic alpine Lake Cadagno: orographical and biogeochemical description. Aquat Sci 63:70-90

DEV (Deutsche Einheitsverfahren) (2000) Deutsche Einheitsverfahren zur Wasser-, Abwasser- und SchlammUntersuchung. Physikalische, chemische, biologische und bakteriologische Verfahren. Fachgruppe in der GDCh Wasserchemische Gesellschaft und Deutsches Institut für Normung (DIN). Wiley-VCH, Weinheim

DeWeerd KA, Mandelco L, Tanner RS, Woese CR, Suflita JM (1990) Desulfomonile tiedjei gen. nov. and sp. nov., a novel anaerobic, dehalogenating, sulfate-reducing bacterium. Arch Microbiol 154:23-30

Egli K, Wiggli M, Klug J, Bachofen R (1998) Spatial and temporal dynamics of the cell density in a plume of phototrophic microorganisms in their natural environment. Doc Ist Ital Idrobiol 63:121-126

Eichler B, Pfennig N (1988) A new purple sulfur bacterium from stratified freshwater lakes, Amoebobacter purpureus sp. nov. Arch Microbiol 149:395-400

Finster K, Liesack W, Thamdrup B (1998) Elemental sulfur and thiosulfate disproportionation by Desulfocapsa sulfoexigens sp. nov., a new anaerobic bacterium isolated from marine surface sediment. Appl Environ Microbiol 64:119-125

Fischer C, Wiggli M, Schanz F, Hanselmann KW, Bachofen R (1996) Light environment and synthesis of bacteriochlorophyll by populations of Chromatium okenii under natural environmental conditions. FEMS Microbiol Ecol 21:1-9

Gilboa-Garber N (1971) Direct spectrophotometric determination of inorganic sulfide in biological materials and in other complex mixtures. Anal Biochem 43:129-133

Glöckner FO, Amann RI, Alfreider A, Pernthaler J, Psenner R, Trebesius K, Schleifer KH (1996) An optimized in situ hybridization protocol for planktonic bacteria. Syst Appl Microbiol 19:403-406

Hanselmann KW, Hutter R (1998) Geomicrobiological coupling of sulfur and iron cycling in anoxic sediments of a meromictic lake: sulfate reduction and sulfide sources and sinks in Lake Cadagno. Doc Ist Ital Idrobiol 63:85-98

Imhoff JF (2001) Transfer of Pfennigia purpurea Tindall 1999 (Amoebobacter purpureus Eichler and Pfennig 1988) to the genus Lamprocystis as Lamprocystis purpurea comb. nov. Int J Syst Evol Microbiol 51:1699-1701

Janssen PH, Schuhmann A, Bak F, Liesack W (1996) Disproportionation of inorganic sulfur compounds by the sulfatereducing bacterium Desulfocapsa thiozymogenes gen. nov., sp. nov. Arch Microbiol 166:184-192

Lehmann C, Lüthy L, Bachofen R (1998) Tools for the evalua- tion of sources and sinks of sulfide in Lake Cadagno. Doc Ist Ital Idrobiol 63:99-104

Lovely DR, Phillips EJP (1994) Novel processes for anaerobic sulfate reduction from elemental sulfur by sulfate-reducing bacteria. Appl Environ Microbiol 60:2394-2399

Lüthy L, Fritz M, Bachofen R (2000) In situ determination of sulfide turnover rates in a meromictic alpine lake. Appl Environ Microbiol 66:712-717

Manz W, Amann R, Ludwig W, Wagner M, Schleifer KH (1992) Phylogenetic oligodeoxynucleotide probes for the major subclasses of proteobacteria: problems and solutions. Syst Appl Microbiol 15:593-600

Manz W, Eisenbrecher M, Neu TR, Szewzyk U (1998) Abundance and spatial organization of Gram-negative sulfatereducing bacteria in activated sludge investigated by in situ probing with specific 16S rRNA targeted oligonucleotides. FEMS Microbiol Ecol 25:43-61

Mas J, Van Gemerden H (1995) Storage products in purple and green sulfur bacteria. In: Blankenship RE, Madigan MT, Bauer CE (eds) Anoxygenic photosynthetic bacteria. Kluwer Academic Publishers, Dordrecht, p 973-990

Pace NR (1999) Microbial ecology and diversity. ASM News 65:328-333

Peduzzi R, Demarta A, Tonolla M (1993) Dynamics of the autochthonous and contaminant bacterial colonization of lakes (Lake Cadagno and Lake of Lugano as model systems). In: Vernet JP (ed) Studies in environmental science, Vol 55: Environmental contamination. Elsevier Science Publishers, Amsterdam, p 323-335

Rabus R, Fukui M, Wilkes H, Widdel F (1996) Degradative capacities and 16S rRNA-targeted whole-cell hybridization of sulfate-reducing bacteria in an anaerobic enrichment culture utilizing alkylbenzenes from crude oil. Appl Environ Microbiol 62:3605-3613

Sun B, Cole JR, Tiedje JM (2001) Desulfomonile limimaris sp. nov., an anaerobic dehalogenating bacterium from marine sediments. Int J Syst Evol Microbiol 51:365-371

Thamdrup B, Finster K, Hansen JW, Bak F (1993) Bacterial disproportionation of elemental sulfur coupled to chemical reduction of iron or manganese. Appl Environ Microbiol 59:101-108

Tonolla M, Demarta A, Hahn D, Peduzzi R (1998a) Microscopic and molecular in situ characterization of bacterial populations in the meromictic Lake Cadagno. Doc Ist Ital Idrobiol 63:31-44

Tonolla, M, Demarta A, Peduzzi R (1998b) The chemistry of Lake Cadagno. Doc Ist Ital Idrobiol 63:11-17

Tonolla M, Demarta A, Peduzzi R, Hahn D (1999) In situ analysis of phototrophic sulfur bacteria in the chemocline of meromictic Lake Cadagno (Switzerland). Appl Environ Microbiol 65:1325-1330

Tonolla M, Demarta A, Peduzzi S, Hahn D, Peduzzi R (2000) In situ analysis of sulfate-reducing bacteria related to Desulfocapsa thiozymogenes in the chemocline of meromictic Lake Cadagno (Switzerland). Appl Environ Microbiol 66:820-824

Wagener S, Schulz S, Hanselmann KW (1990) Abundance and distribution of anaerobic protozoa and their contribution to methane production in Lake Cadagno (Switzerland). FEMS Microbiol Ecol 74:39-48

Zarda B, Hahn D, Chatzinotas A, Schönhuber W, Neef A, Amann RI, Zeyer J (1997) Analysis of bacterial community structure in bulk soil by in situ hybridization. Arch Microbiol 168:185-192

Zinder SH, Salyers AA (2001) Microbial ecology-new directions, new importance. In: Boone DR, Castenholz RW (eds) Bergey's manual of systematic bacteriology. Williams \& Wilkins, Baltimore, p 101-109

Submitted: May 7, 2002; Accepted: November 18, 2002

Proofs received from author(s): January 7, 2003 